\title{
Efisiensi Pada Usahatani Padi Sawah di Desa Noelbaki, Kabupaten Kupang, NTT
}

\author{
Yosefa Bernadina Nitit Ritan ${ }^{1}$, Johanna Suek ${ }^{1 *}$, Sondang Pudjiastuti ${ }^{1}$ \\ ${ }^{1}$ Fakultas Pertanian, Universitas Nusa Cendana, Kota Kupang - NTT, Indonesia \\ *Correspondence email : johanna.suek@gmail.com
}

\section{Article Info}

\section{Article history:}

Received 06 August 2021

Received in revised from 13 August 2021

Accepted 26 October 2021

DOI: https://doi.org/10.32938/ag.v6i4.1450

Keywords:

Allocative and Economic Efficiency

Stochastic Frontier

Technical Efficiency

\begin{abstract}
Abstrak
The use of production factors in rice paddy farming has not been efficient, how efficient the use of production factors is carried out through studies aimed at estimating production factors that affect rice paddy farming and measuring the level of efficiency. The research was conducted in Noelbaki Village of Central Kupang District of Kupang Regency. The study used 60 farmers, who were randomly taken. Data analysis uses the production function and the Cobb-Douglas stochastic frontier cost function. The results of the study showed that the factors of widespread production of land, seeds, fertilizers, labor had a real effect on rice paddy production while pesticide production factors had no real effect. The use of factor inputs in rice paddy farming can be said to be quite efficient technically and economically with an average value of 0.81 and 0.84 , respectively. While the alloative efficiency is very efficient with an average value of 0.99 .
\end{abstract}

\section{Pendahuluan}

Beras merupakan komoditas terpenting saat ini dan dijadikan makanan pokok sehari-hari oleh hampir seluruh masyarakat Indonesia dan tuntutan akan peningkatan produksi beras menjadi sangat tinggi. Penggunaan faktor produksi dan penerapan teknologi merupakan dua hal yang memegang peranan penting (Soekartawi, 2010) dalam pembangunan pertanian, sehingga perlu diperhatikan dalam aplikasinya agar sesuai yang dibutuhkan. Lebih lanjut oleh Soekartawi dikemukakan bahwa penerapan teknologi kurang tepat dapat mengakibatkan produksi rendah dan biaya usahatani yang tinggi. Proporsi penggunaan faktor produksi yang tepat dan sesuai diperlukan bagian dari studi ini untuk menelaah faktor produksi mana yang harus ditambah dan mana yang harus dikurangi sehingga penggunaan faktor produksi tersebut bisa optimal.

Produksi padi di Provinsi Nusa Tenggara Timur, rata-rata produksinya belum mampu bersaing dengan provinsi lainnya. Sementara dari ketersediaan lahan, Propinsi NTT memiliki luas lahan sawah 198.867,41 hektar, merupakan potensi yang cukup besar untuk dikembangkan usahatani padi (BPS Indonesia, 2020). Produksi padi di NTT berdasarkan urutan kabupaten terlihat bahwa Kabupaten Manggarai Barat merupakan kabupaten dengan produksi padi terbesar yakni 121.439,66 ton, kemudian Kabupaten Manggarai sebesar 92.028,75 ton, Kabupaten Manggarai Timur sebesar 88.987,82 ton, Sumba Timur sebanyak 68.917,07 ton dan Kabupaten Kupang sebanyak 61.592,67 ton (BPS NTT, 2020).

Dalam proses produksi, kegiatan pemanfaatan sumber daya secara efisien dan efektif dilakukan untuk mendapatkan hasil maksimal. Sumberdaya yang dimanfaatkan antara lain lahan, tenaga kerja, modal dan manajemen (Shinta, 2011). Ada juga faktor nonteknis yang mempengaruhi produksi usahatani misalnya hal yang menghalangi petani untuk menggunakan teknologi yang direkomendasikan. Faktor non teknis meliputi pengetahuan petani yang diindikasikan dengan pengalaman petani dalam berusahatani, prasarana transportasi yang diindikasikan melalui jarak lahan garapan dengan tempat tinggal petani. Dalam studi yang dilakukan, investigasi faktor produksi bersifat teknis saja. Penggunaan faktor produksi yang efisien, dapat dicapai dengan meminimalkan sumber daya yang dibutuhkan untuk memproduksi output tertentu, atau memaksimalkan output yang dihasilkan dari sumber daya tertentu. Dengan kata lain pemanfaatan input faktor yang efisien dapat meningkatkan produktivitas (Rasmussen, 2011). Lebih lanjut Dalam tulisan Rasmussen (2011) dijelaskan efisiensi merupakan perbandingan antara produktivitas aktual relatif dan produktivitas potensial maksimum yang dicapai. Dalam produksi frontier, batas produksi terbaik yang dapat dicapai merupakan maksimum produktifitas potensial. Studi tentang efisiensi pada berbagai tanaman pangan dengan menggunakan analisis frontier telah banyak dilakukan pada usahatani padi (Sumaryanto, dkk, 2003; Kurniawan, 2012; Tinaprilla, dkk, 2013) dan efisiensi pada usahatani jagung (Kune et al., 2016). Selain itu, efisiensi pada sistem usahatani agroforestri dan non agrogorestri dilakukan Suek (2018), dan pada usahatani lahan kering (Mustafa, et al, 2019).

Tiga komponen efisiensi yang ditelaah meliputi efisensi teknis yaitu kemampuan suatu usahatani dalam memperoleh output maksimal dari pemakaian jumlah input tertentu. Efisensi alokatif yakni kemampuan usahatani dalam menggunakan input secara optimal sesuai dengan harga serta teknologi yang dimilikinya. Efisensi ekonomi yaitu bahwa pilihan apapun teknik yang digunakan dalam kegiatan produksi haruslah yang meminimumkan biaya (Rasmussen, 2011). Pentingnya dilakukan analisis efisensi produksi agar petani dapat memanfaatkan sumberdaya dalam hal ini faktor-faktor produksi yang ketersediaannya terbatas untuk memperoleh 
keuntungan yang maksimal (Kusnadi, dkk. 2011). Faktor produksi apa saja yang memberikan efek nyata terhadap produksi padi sawah dan seberapa besar tingkat efisiensi penggunaan faktor produksi pada usahatani padi sawah, merupakan tujuan dari studi yang dilakukan.

\section{Metode}

Lokasi penelitian ditentukan secara purposive sampling dengan pertimbangan desa Noelbaki adalah merupakan salah satu desa sentra produksi padi sawah di Kabupaten Kupang, memiliki akses transpotasi yang mudah dan gampang terjangkau (BPS Kecamatan, 2020). Studi berlangsung selama 3 bulan dari bulan Juli sampai September 2020. Populasi studi adalah petani pemilik lahan sawah di lokasi penelitian yaitu 302 petani, darinya diambil secara acak (simple random sampling) sebanyak 20\% sehingga diperoleh sampel penelitian 60 petani. Jenis data yang digunakan adalah data primer dan data sekunder. Analisa data menggunakan fungsi produksi yang diasumsikan mempunyai bentuk Cobb-Douglas kemudian ditransformasikan ke dalam bentuk linier logaritma natural. Bentuk umum fungsi produksi Cobb-Douglass adalah secara metematis dirumuskan sebagai berikut (Soekartawi, 2004):

Dimana:

$$
\mathrm{Y}=\mathrm{a} X 1^{b 1} X 2^{b 2} \quad X 3^{b 3} \ldots \ldots \ldots \ldots . . . . \ldots n^{b n} e^{u}
$$

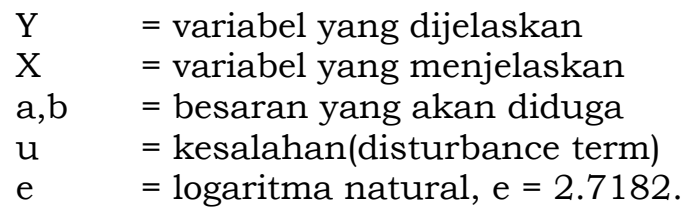

Balam bentuk linier logaritma natural sebagai berikut:

$$
\mathrm{LnY}=\beta_{0}+\beta_{1} \ln X_{1}+\beta_{2} \ln X_{2}+\beta_{3} \ln X_{3}+\beta_{4} \ln X_{4}+(v i-u i)
$$

Dimana:

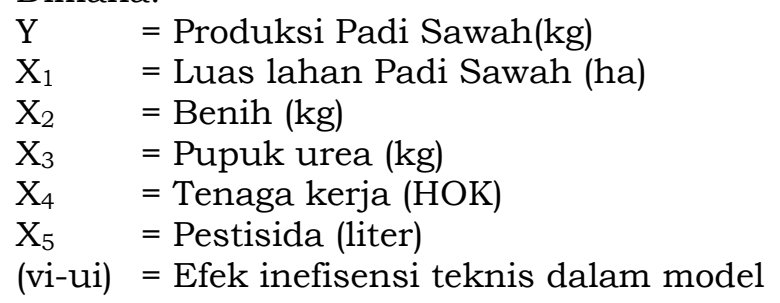

Efisiensi teknis dianalisis menggunakan model fungsi produksi stochastic frontier dengan metode estimasi Maximum Likelihood Estimate (MLE) dengan program frontier 4.1. Selanjutnya untuk mengestimasi efisiensi ekonomi dengan terlebih dahulu dicari nilai efisensi biaya. Model Analisis efisiensi biaya digunakan model efisensi biaya Cobb-Douglas Stochastic Frontier, secara matematis dapat ditulis sebagai berikut:

Dimana:

$$
C=e^{\beta 0} p_{1}^{\beta 1} p_{2}^{\beta 2} p_{3}^{\beta 3} p_{4}^{\beta 4} p_{5}^{\beta 5} y_{i}^{\beta 6} e^{(v i+u i)}
$$

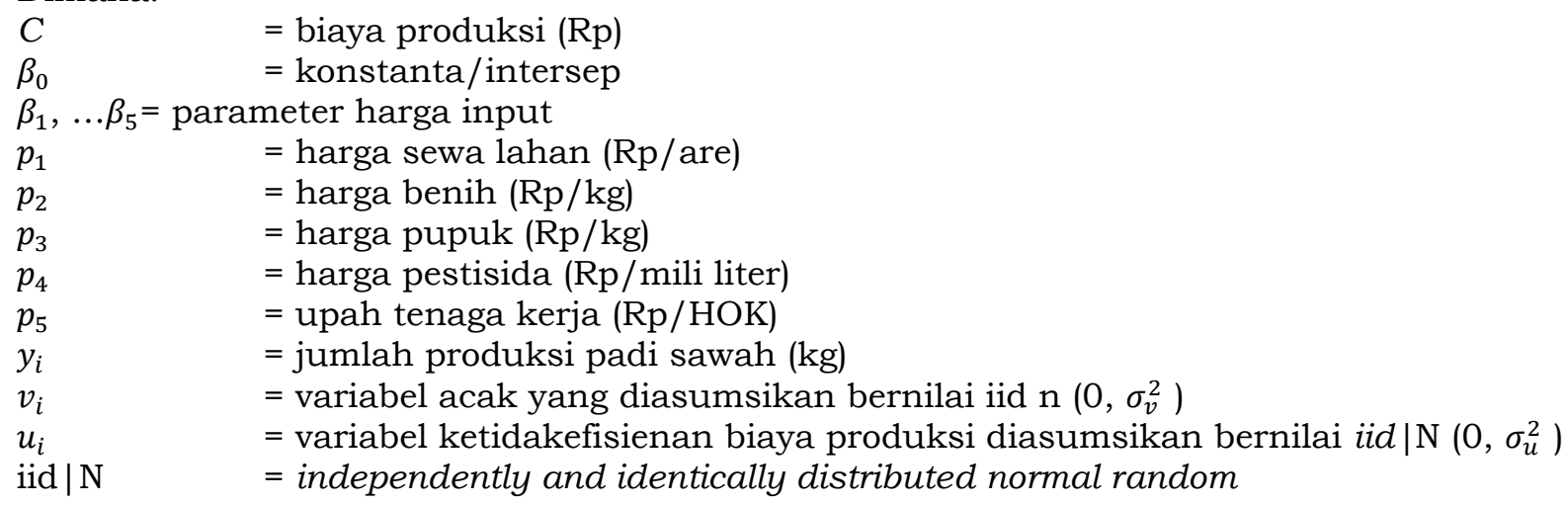

Efisiensi teknis dianalisis menggunakan model fungsi produksi stochastic frontier dengan metode estimasi Maximum Likelihood Estimate (MLE) dengan program frontier 4.1. Model yang sama digunakan untuk memperoleh nilai efisensi ekonomi, formulasinya: 
Di mana:

$$
\mathrm{EE}=1 / E B
$$

$\mathrm{EE} \quad=$ Efisiensi Ekonomi

$\mathrm{EB} \quad=$ Efisiensi Biaya

Efisiensi alokatif diperoleh dengan formulasi rumus

Dimana:

$$
\mathrm{EA}=E T / E E
$$

EA $\quad=$ efisensi alokatif

ET = efisensi teknis

$\mathrm{EE} \quad=$ efisiensi ekonomi

Tingkat efisiensi kemudian diklasifikasikan menurut klasifikasi belum efisiensi <0,70; cukup efisiensi pada interval 0,71-0,90 dan Efisien jika >0,90.

\section{Hasil dan Pembahasan}

\section{Gambaran Umum Lokasi dan Profil Petani Responden}

Desa Noelbaki memiliki luas wilayah sebesar $14,31 \mathrm{~km}^{2}$, dengan jumlah penduduk sebanyak 11.158 jiwa dimana $12 \%$ diantaranya bermata pencaharian disektor pertanian dan peternakan, dan kepadatan geografis 780 jiwa $/ \mathrm{km}$. Desa Noelbaki terletak di poros jalan Nasional Timor Raya, memiliki 2.665 KK dan terdapat sekitar $302 \mathrm{KK}$ adalah petani yang tersebar di lima dusun. Penduduk desa Noelbaki, 60\%-nya adalah berpendidikan SMP ke bawah, sisanya 40\% berpendidikan SMA hingga Perguruan Tinggi (Dukcapil Kemendagri, 2021). Mata pencaharian cukup beragam, dan merupakan salah satu desa sentra produksi padi di Kabupaten Kupang.

Profil petani responden dilihat dari beberapa variabel seperti umur, pengalaman berusahatani, pendidikan dan lahan yang dimiliki. Semakin berumur seorang petani disertai dengan pendidikan/pengetahuan yang baik, dan pengalaman dalam menjalankan usahatani diharapkan dapat menambah wawasan dan ketrampilan petani dalam meningkatkan efisiensi usahataninya. Begitu pula, semakin luas lahan yang dikelola disertai ketersediaan sumberdaya yang memadai dipadukan dengan kemampuan/ketrampilan mengelola dalam proses produksi turut menentukan tingkat efisiensi suatu usahatani. Variasi luas lahan sangat tinggi dibandingkan dengan variable yang lain dilihat dari nilai simpangan bakunya. Hal ini menunjukkan bahwa rentang luas lahan yang dimiliki petani antar petani cukup lebar, walaupun secara proporsi kepemilikan relatif merata pada setiap klasifikasi luas lahan. Pada klasifikasi luas lahan kurang dari 0,5 ha terdapat 34\% petani, klasifikasi antara 0,51-0,75 ha dimiliki oleh $35 \%$ dan klasifikasi lebih dari 0,75 ha dikuasai oleh $31 \%$ petani.

Jika ditelusuri dari klasifikasi umur petani, terdapat 50\% petani berada pada interval 50 tahun ke atas, $27 \%$ petani berada pada interval 41 - 50 tahun dan $23 \%$ petani berada selang $21-$ 40 tahun. Tingginya persentasi petani pada klasifikasi umur di atas 50 tahun sangat mengkuatirkan jika pada 10 - 20 tahun yang akan datang kurangnya peminat anak muda bekerja di sektor pertanian. Oleh karena itu diperlukan dorongan, motivasi dan revitalisasi pertanian sehingga anak muda tertarik bekerja dalam sektor pertanian.

Tabel 1. Rata-rata Umur Petani, Pengalaman Bertani, Luas Lahan Yang Dimiliki dan Jumlah Tanggungan Keluarga Petani Responden di Desa Noelbaki.

\begin{tabular}{lcccc}
\hline Indikator & $\begin{array}{c}\text { Umur Petani } \\
\text { (tahun) }\end{array}$ & $\begin{array}{c}\text { Pengalaman } \\
\text { Berusahatani } \\
\text { (Tahun) }\end{array}$ & Luas Lahan (Are) & $\begin{array}{c}\text { Jumlah Anggota } \\
\text { Rumah tangga (Jiwa) }\end{array}$ \\
\hline rata-rata & 49,32 & 27,30 & 76,20 & 3,97 \\
\hline SD & 11,92 & 15,39 & 31,84 & 1,91 \\
\hline
\end{tabular}

Sumber: Data Primer, diolah. 2020

Informasi mengenai pengalaman bertani, terdapat 25\% petani yang sudah berpengalaman bertani selama 40 tahun ke atas, 40\% pada kisaran pengalaman 21 sampai 40 tahun dan $35 \%$ petani yang berpengalaman berusahatani kurang dari 20 tahun. Aspek pendidikan petani memperlihatkan bahwa teradapat 53\% petani berpendidikan SD, 20\% SMP dan sekitar $27 \%$ petani yang berpendidikan SMA ke atas. Dari aspek jumlah anggota rumahtangga terdapat $58 \%$ petani yang memiliki jumlah anggota keluarga lebih dari 4 orang. Semakin banyak anggota 
keluarga menunjukan dua pemahaman berbeda dalam rumah tangga. Pertamna, semakin tinggi jumlah anggota keluarga dapat dikatakan semakin tinggi ketersediaan tenaga kerja dan kedua, sekaligus semakin tinggi beban pemenuhan kebutuhan pangan mereka.

\section{Faktor Input yang Berpengaruh terhadap Produksi Padi Sawah}

Faktor input yang digunakan dalam analisis adalah luas lahan, benih, pupuk, pestisidan dan tenaga kerja. Hasil analisis ditemukan bahwa Nilai sigma-square $\left(\sigma^{2}\right)$ dan gamma $(\gamma)$ masingmasing yang diperoleh dari pendugaan dengan metode MLE adalah sebesar 0,0804 dan 0,9100. Artinya terdapat pengaruh inefisensi teknis dalam model fungsi produksi dan variasi hasil di antara petani sampel disebabkan oleh komponen inefisensi teknis sebesar skor tersebut di atas.

Luas lahan, mempunyai pengaruh yang positif dan signifikan $(\alpha=1 \%)$ artinya, apabila terjadi kenaikan penggunaan luas lahan, akan meningkatkan produksi padi sawah. Lahan merupakan sumberdaya utama dan yang diandalkan bagi petani kecil di Desa Noelbaki. Karena dari lahan yang dimiliki dan diusahakan itulah merupakan sumber pangan keluarga tani. Oleh karena itu, lahan memiliki peran yang signifikan. Hasil studi ini sejalan dengan hasil yang ditemukan dalam penelitian Kalaba dan Rahmat (2017) yang mana variabel luas lahan berpengaruh positif dan signifikan pada produksi padi sawah.

Faktor produksi benih tidak memberikan pengaruh negatif pada tingkat nyata pada $(\alpha=$ 5\%) Walaupun begitu, dilihat ada kecenderungan penggunaan benih yang berlebihan sehingga menurunkan produksi padi. Kondisi di Desa Noelbaki, memperlihatkan penggunaan benih sudah penelitian melebihi dari rekomendasi penggunaan input benih per hektarnya. Penggunaan benih yang berlebihan ini juga diduga sebagai antisipasi kegagalan tanam oleh petani, mengingat pulau Timor masuk dalam zona iklim semi arid yang memiliki tingkat kegagalan panen cukup tinggi. Dalam kajian oleh Rozen (2018) dijelaskan bahwa penggunaan benih yang dianjurkan adalah 30$45 \mathrm{~kg} / \mathrm{ha}$, sedangkan rata-rata penggunaan benih dilokasi penelitian ialah sekitar $0,60 \mathrm{~kg} / \mathrm{are}$ atau $60 \mathrm{~kg} / \mathrm{ha}$. Jumlah penggunaan benih yang berlebihan berdampak pada penurunan produksi padi sawah. Secara agronomis penggunaan benih yang berlebihan tidak memberikan kontribusi yang positif karena akan terjadi persaingan antar tanaman dalam menyerap unsur hara dan sinar matahari, hal ini diduga sebagai penghambat dalam pertumbuhan tanaman yang mengakibatkan produksi yang dihasilkan menjadi rendah. Kajian ini serupa disampaikan dalam studi yang dilakukan oleh Husnaini (2016) bahwa kenaikan produktivitas yang tidak berarti atau cenderung menurun diperlukan perbaikan penggunaan alsintan dan input produksi seperti pupuk dan benih.

Tabel 2. Hasil Estimasi Parameter Fungsi Produksi Stochastic Frontier Padi Sawah di Desa Noelbaki dengan Pendekatan Maximum Likelihood Estimate (MLE) dengan Program frontier 4.1

\begin{tabular}{lrrr}
\hline Variable & Koefisien & Standar- Error & t-Rasio \\
\hline konstanta & 2,6592 & 0,4859 & $5,4722^{* *}$ \\
Luas lahan & 0,9559 & 0,1443 & $6,6226^{* *}$ \\
Benih & $-0,1280$ & 0,0791 & $-1,61777^{\mathrm{ns}}$ \\
Pupuk & 0,2029 & 0,0751 & $2,7009^{* *}$ \\
Pestisida & 0,0456 & 0,0550 & $0,8282^{\mathrm{ns}}$ \\
Tenaga kerja & 0,1259 & 0,0869 & $1,44966^{\mathrm{ns}}$ \\
Sigma Squared & 0,0804 & 0,0268 & 0,7846 \\
Gamma (y) & 0,9100 & 0,1200 & 2,9923 \\
Log likehood function & 18,9987 & - & \\
LR Test of the one sided eror & 0,55057 & - & \\
\hline
\end{tabular}

Sumber: Data primer diolah, 2020

keterangan:

** $\quad$ : signifikan pada taraf $\alpha=1 \%(t$-tabel $=2,576)$

ns : tidak signifikan

Faktor produksi pupuk, mempunyai pengaruh positif dan signifikan $(\alpha=1 \%)$ terhadap produksi padi, artinya setiap penambahan $1 \%$ faktor produksi pupuk maka akan meningkatkan produksi padi sawah sebesar 0,2029\%. Penggunaan pupuk oleh petani masih dalam jumlah yang relatif sedikit, sehingga sangat responsif. Studi yang dihasilkan sejalan dengan temuan penelitian Rahmanta (2011) yang dijelaskan bahwa variabel pupuk berpengaruh positif dan signifikan terhadap peningkatan produksi padi sawah.

Faktor tenaga kerja dan lahan merupakan sumber daya penting yang tersedia dalam rumahtangga petani kecil. Hasil analisis menunjukkan bahwa tenaga kerja tidak berpengaruh terhadap produksi padi pada tingkat nyata $(a=5 \%)$. Tidak signifikansi variable tenaga kerja diduga karena penggunaan tenaga kerja tampaknya mulai berlebihan. Oleh karena itu 
produktivitas tenaga kerja harus ditingkatkan disertai dengan pengurangan kuantitasnya mengingat kebiasaan penggunaan tenaga kerja luar rumahtangga secara borongan (kelompok) saat tanam dan panen. Temuan dalam studi Kune (2016) dijelaskan bahwa penggunaan tenaga kerja harus perlu diperhatikan karena penggunaan tenaga kerja merupakan faktor penting dalam proses usahatani

Faktor Produksi pestisida tidak memperlihatkan respon yang signifikan terhadap produksi padi. Keberhasilan penggunaan pestisida tergantung pada jenis pestisida yang sesuai dengan hama dan penyakit serta dosis, cara dan waktu pemberian. Sehingga ketidaksesuaian salah satu aspek pemberian dapat menyebabkan pengaruh yang tidak signifikan terhadap produksi padi sawah. Oleh karenanya perlu dilakukan upaya perlindungan tanaman yang lebih ramah lingkungan misalnya dengan menggunakan bahan organik. Dalam kajian Nurlaela (2018) dijelaskan bahwa sebaiknya petani menggunakan pestisida ketika diperlukan saja misalnya pada saat mulai terlihat ada gangguan hama, penyakit dan sebelum masa panen.

\section{Efisiensi}

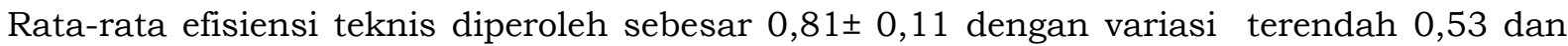
tertinggi 0,96. Merujuk pada data pengklasifikasian pada tingkat efisiensi teknis terdapat sekitar $83,33 \%$ petani yang memiliki kemampuan manajerial cukup baik dengan kondisi eksisting terutama dalam mengkombinasikan berbagai sumberdaya tersedia.

Tabel 3. Efisiensi Teknis, Alokatif dan Efisiensi Ekonomi usahatani padi sawah di Desa Noelbaki menurut Sebaran Petani pada setiap Interval Kelas

\begin{tabular}{|c|c|c|c|c|c|c|}
\hline \multirow[b]{2}{*}{ Sebaran Efisiensi } & \multicolumn{2}{|c|}{ Efisiensi Teknis } & \multicolumn{2}{|c|}{ Efisiensi Ekonomi } & \multicolumn{2}{|c|}{ Efisien Alokatif } \\
\hline & $\begin{array}{l}\text { Petani } \\
\text { (orang) }\end{array}$ & $\begin{array}{l}\text { Persentase } \\
\text { (\%) Petani }\end{array}$ & $\begin{array}{l}\text { Petani } \\
\text { (orang) }\end{array}$ & $\begin{array}{l}\text { Persentase } \\
\text { (\%)Petani }\end{array}$ & $\begin{array}{l}\text { Petani } \\
\text { (orang) }\end{array}$ & $\begin{array}{l}\text { Persentase } \\
\text { (\%)Petani }\end{array}$ \\
\hline$<0,51$ & 0 & 0,00 & 0 & 0,00 & 0 & 0,00 \\
\hline $0,51-0,60$ & 3 & 5,00 & 6 & 10,00 & 1 & 1,67 \\
\hline $0,61-0,70$ & 7 & 11,67 & 12 & 20,00 & 2 & 3,33 \\
\hline $0,71-0,80$ & 16 & 26,67 & 6 & 10,00 & 7 & 11,67 \\
\hline $0,81-0,90$ & 18 & 30,00 & 3 & 5,00 & 12 & 20,00 \\
\hline $0,91-1,0$ & 16 & 26,67 & 33 & 55,00 & 20 & 33,33 \\
\hline$>1,0$ & 0 & 0,00 & 0 & 0,00 & 18 & 30,00 \\
\hline Total & 60 & 100 & 60 & 100,00 & 60 & 100,00 \\
\hline Rata-rata & \multicolumn{2}{|c|}{0,81} & \multicolumn{2}{|c|}{0,84} & \multicolumn{2}{|c|}{0,99} \\
\hline St.Deviasi & \multicolumn{2}{|c|}{0,11} & \multicolumn{2}{|c|}{0,15} & \multirow{2}{*}{\multicolumn{2}{|c|}{$\begin{array}{c}0,21 \\
0,54-1,41\end{array}$}} \\
\hline Interval & \multicolumn{2}{|c|}{$0,53-0,96$} & \multicolumn{2}{|c|}{$0,53-1,00$} & & \\
\hline
\end{tabular}

Sumber: Data primer diolah, 2020

Masih terdapat sekitar $16,67 \%$ petani belum mencapai tingkat efisiensi teknis, artinya masih cukup banyak petani yang belum mengalokasikan input produksi secara optimal. Sebagian petani masih berorientasi untuk pemenuhan kebutuhan subsistensinya. Pengelolaan belum dipisahkan antara rumahtangga sebagai pengusaha (produsen) dan rumahtangga konsumen. Penggunaan tenaga kerja masih dilakukan dengan kerja borongan dalam jumlah yang banyak, sehingga efisiensi tenaga kerja rendah. Selain itu, penggunnan benih masih cukup tinggi dibandingkan dengan jumlah yang direkomendasikan. Oleh karena itu, untuk mencapai tingkat efisiensi teknis yang memadai, petani masih perlu didorong dan dimotivasi. Studi ini berbeda dalam jumlah petani yang belum mencapai efisiensi dibandingkan dengan temuan oleh Kurniawan (2012) yang mana hanya terdapat 3,94\% petani yang belum mencapai nilai efisiensi yang cukup. Rata-rata tingkat efisiensi yang diperoleh juga lebih yakni $96 \%$. Ini artinya kajian Kurniawan pada usahatani padi lahan pasang turut memberikan performa efisiensi teknis yang lebih baik.

Nilai rata-rata efisiensi teknis diperoleh dari hasil penelitian sebesar 0,81 atau $81 \%$ mengindikasikan masih ada peluang sebesar $16 \%$ (dari 1-0,81/0,94) bagi petani memperbaiki (upgrade) performa efisiensi teknis untuk mencapai tingkat efisiensi teknis yang tertinggi.

Perolehan nilai efisiensi Ekonomi terlebih dahulu dilakukan dengan menganalisis fungsi biaya dual yang diperoleh dari fungsi produksi Cobb-Douglas dan fungsi biaya input dengan hasil analisis disajikan pada Tabel 3.

Hasil analisis memperlihatkan bahwa variabel luas lahan, dan pestisida bernilai positif, yang berarti variabel luas lahan dan pestisida meningkatkan total biaya produksi, dengan asumsi faktor produksi lain dianggap tetap. Terdapat dua variabel dari hasil uji t-rasio secara statistik 
signifikan pada taraf $1 \%$ yakni harga lahan dan harga pestisida. Sementara harga pupuk dan benih tidak meningkatkan total biaya produksi secara signifikan.

Tabel 4. Efisiensi Biaya Produksi Stochastic Frontier Usahatani Padi Sawah di Desa Noelbaki dengan metode MLE

\begin{tabular}{lrrr}
\hline Variable & Koefisien & Standar- Error & t- Ratio \\
\hline konstanta & 9,1974 & 0,3660 & $25,1271^{* *}$ \\
Luas lahan & 0,5981 & 0,1714 & $3,4893^{* *}$ \\
Benih & $-0,3281$ & 0,1928 & $-1,7019^{n s}$ \\
Pupuk & 0,0917 & 0,0773 & $1,1859^{n s}$ \\
Pestisida & 0,0935 & 0,0391 & $2,3867^{* *}$ \\
Sigma Squared & 0,0717 & 0,0145 & 4,9222 \\
Gamma $(y)$ & 0,9999 & 0,0424 & 235,6661 \\
Log likehood function & 35,0034 & - & - \\
LR Test of the one sided eror & 27,8255 & - & -
\end{tabular}

Sumber: data primer diolah, 2020

keterangan:

** $\quad$ : signifikan pada taraf $\alpha=1 \%(t$-tabel $=2,576)$

Berdasarkan analisis efisiensi biaya ditemukan rata-rata nilai efisiensi ekonomis (Tabel 2) sebesar $0,84 \pm 0,15$. Rata-rata efisiensi ekonomi sebesar 0,84 , rataan ini mengidentifikasikan bahwa petani masih memiliki mempunyai peluang sebesar $16 \%(1-0,84 / 1,00)$ memperbaiki performa kerjanya untuk mencapai efisiensi ekonomi tertinggi. Kajian serupa dilakukan oleh Hadiana (2007), ditemukan bahwa setiap petani memiliki nilai efisiensi ekonomi yang berbeda, diakibatkan oleh kinerja masing-masing petani. Kinerja petani dipengaruhi oleh faktor internal seperti akses terhadap input dan akses terhadap koperasi dan lembaga keuangan lainnya serta kondisi sumberdaya alam.

Efisiensi alokatif atau efisiensi harga menunjukkan hubungan biaya dengan input. Efisiensi alokatif tercapai jika petani mampu memaksimalkan keuntungan yaitu menyamakan nilai produk marginal setiap faktor produksi dengan harganya. Hasil analisis pada Tabel 2 memperlihatkan bahwa rata -rata efisiensi alokatif sebesar 0,99 $\pm 0,21$ dengan variasi terendah 0,54 dan tertinggi 1,44. Rataan efisiensi alokatif sebesar 0,99 memperlihatkan bahwa nilai ratarata efisiensi alokatif yang diperoleh masuk dalam klasifikasi sangat efisien $(>0,90)$. Nilai ratarata tersebut mengindikasikan pula bahwa jika petani ingin mencapai tingkat efisiensi alokatif tertinggi, maka ia petani dapat menghemat biaya sebesar 29\% $(1-0,99 / 1,41)$ sedangkan untuk petani yang tidak efisien dapat menghemat biaya sebesar $61 \%(1-0,54 / 1,41)$. Efek perbandingan antara efisiensi teknis dan ekonomi menunjukkan bahwa sebagian besar petani sudah mencapai tingkat efisiensi alokatif sebesar 63,33\%., 31,67\% petani pada interval cukup efisiensi alokatif dan sekitar 5\% petani yang belum mencapai tingkat efisiensi alokatif. Hasil kajian Oni, dkk (2020) pada usahatani jagung manis di Kecamatan Kupang Timur ditemukan bahwa terdapat $49,37 \%$ petani jagung masih berada kondisi belum efisien secara alokatif. Masih tingginya persentase petani yang belum mencapai efisiensi secara alokatif diduga karena kecamatan Kupang Timur merupakan daerah sentra produksi beras (usahatani padi sawah) sehingga perhatian petani lebih diutamakan pada usahatani padi. Selain itu, benih jagung manis bukan seperti benih jagung varitas lokal yang bias tahan untuk disimpan oleh petani dari hasil panen sebelumnya. Harga benih jagung manis berkisar antara Rp 44.000 (200 biji) sampai Rp 166.000 (1.800 biji) tergantung jumlah biji atau butirnya. Jika jumlah benih jagung sekitar 2200 sampai 3000 biji, dan jumlah benih yang dibutuhkan sebesar 20 sampai $25 \mathrm{~kg}$, maka biaya produksi jagung dari benih cukup tinggi. Studi tentang komponen ketiga efisiensi menggunakan model frontier pada sistem wanatani mamar dan non mamar ditemukan bahwa rata-rata efisien teknis, alokatif dan efisiensi ekonomi pada sistem usahatai agroforestri secara berurutan sebesar $0,83 \pm 0,11 ; 0,64 \pm 0,16$ dan $0,79 \pm 0,25$. Sementara rata-rata ketiga jenis efisiensi yang ditemukan pada sistem usahatani non mamar masing-masing adalah $0,85 \pm 0,11 ; 0,82 \pm 0,05$ dan $0,99 \pm 0,19$ (Suek, 2018).

Berdasarkan data Tabel 2 memperlihatkan nilai standar deviasi pada efisiensi teknis, ekonomis dan alokatif masing-masing sebesar 0,$11 ; 0,15$ dan 0,21. Data simpangan ini mengindikasikan bahwa variasi efisiensi terbesar berada pada efisiensi alokatif. Hal ini dapat dimengerti karena fluktuasi harga input menentukan tingkat efisiensi biaya dan pada akhirnya mempengaruhi efisiensi alokatif. Simpangan baku pada efisiensi alokatif pada sistem wanatani mamar di atas menunjukan perilaku data yang relatif sama. 


\section{Simpulan}

Faktor-faktor produksi yang mempengaruhi secara signifikan terhadap produksi usahatani padi sawah adalah luas lahan, benih, pupuk dan tenaga kerja. Rata-rata nilai efisiensi yang diperoleh pada usahatani padi yakni efisiensi teknis sebesar 0,81 efisiensi ekonomi 0,84 dan efisiensi alokatif sebesar 0,99. Kombinasi faktor produksi secara baik merupakan suatu proses trial and error yang cukup lama, sehingga dibutuhkan intervensi dari luar untuk mempercepat proses tersebut agar peluang untuk meningkatkan efisiensi terbaik dapat dicapai. Kemudian, penggunaan tenaga kerja yang cukup boros akibat usia sebagian besar pada usia yang lanjut (>50 tahun).

\section{Pustaka}

Badan Pusat Statisitik Provinsi Nusa Tenggara Timur. 2020. Nusa Tenggara Timur dalam Angka Badan Pusat Statisitik Nusa Tenggara Timur. 2020.

Badan Pusat Statistik Kabupaten Kupang. 2019. Kabupaten Kupang Dalam Angka 2019.: Badan Pusat Statistik Kabupaten Kupang. 2019.

Badan Pusat Statistik Kabupaten Kupang. 2020. Kabupaten Kupang Dalam Angka 2020.: Badan Pusat Statistik Kabupaten Kupang. 2020.

Badan Pusat Statistik Negara Indonesia, 2020. Indonesia dalam angka 2020. Badan Pusat Statistik Indonesia. 2020.

Badan Pusat Statistik Kecamatan Kupang Tegah. 2020. Kecamatan Kupang Tengah Dalam Angka 2019.: Badan Pusat Statistik Kabupaten Kupang. 2020.

Hadiana, M. H. 2007. Dampak Faktor Eksternal Kawasan Terhadap Efisiensi Usaha Ternak Sapi Perah (Analisis Berdasarkan Fungsi Biaya Frontier) . Jurnal Ilmu Ternak. Volume 7 Nomor 1. (2007). 2007.

https://media.neliti.com/media/publications/15344-ID-analisis-efisiensi-penggunaan-faktorfaktor-produksi-pada-usahatani-padi-sawah-d.pdf

Husnaini, A. Kasno dan S. Rochyati, 2016. Pengelolaan Hara dan Teknologi Pemupukan Mendukung Swasembada Pangan di Indonesia. Jurnal Sumberdaya Lahan Vol. 10 No. 1, Juli 2016; 25-36

Kalaba Y dan Rahmat . 2017. Analisis Efisiensi Penggunaan Input Produksi Pada Usahatani Padi Sawah di Desa Posona Kecamatan Kasimbar Kabupaten Parigi Moutong. Jurnal : Agrotekbis, Volume 5 nomor 1. Februari. (2017). 5, 2017.

Kune, S.J. dan A.W. Muhaimin dan B. Setiawa. 2016. Analisis Efisiensi Teknis dan Alokatif Usahatani Jagung (Studi Kasus di Desa Bitefa Kecamatan Miomafo Timur Kabupaten Timor Tengah Utara. Agrimor 1(1) 3-6 Jurnal Agribisnis Lahan Kering, 2016 International Standard of Serial Number 2502-1710.

Kurwiawan, A.Y., 2012. Faktor-Faktor yang Mempengaruhi Efisiensi Teknis pada Usahatani Padi Lahan Pasang Surut di Kecamatan Anjir Muara Kabupaten Barito Kuala Kalimantan Selatan. Jurnal Agribisnis Perdesaan Volume 02 Nomor 01 Maret 2012, hal.35-52. Diakses 20210731. https://media.neliti.com/media/publications/9263-ID-faktor-faktor-yangmempengaruhi-efisiensi-teknis-pada-usahatani-padi-lahan-pasan.pdf.

Kusnadi, Tinaprilla, Susilowati \& Purwoto A. 2011. Analisis efisiensi usahatani padi di beberapa sentra produksi padi di Indonesia. Jurnal: agro ekonomi, volume: 29 nomor 1. Mei. (2011). 2011.

Mustafa A., J. Suek, M. Tusan;, P. Un, Ch. Kapioru, 2019. Efisiensi Teknis Usahatani Lahan Kering Desa Noelbaki, Kecamatan Kupang Tengah, Kabupaten Kupang. Jurnal EXCELLENTIA 8 (02), 196-202. http://core.ac.uk/download/pdf/270189105/pdf .

Nurlaela, N. (2018). Analisis Efisiensi Alokasi Faktor-Faktor Produksi Pada Usahatani Padi Sawah di Kecamatan Cibeureum, Kota Tasikmalaya. Fakultas Ekonomi dan Bisnis, Universitas Islam Negeri Syarif Hidayatullah. [Skripsi]. 2018.

Oni, O, Wiendiyati, J. Suek, 2020. Penentuan tingkat Efisiensi Alokatif dan Efisiensi Tekis pada Usahatani Jagung Manis di Kecamatan Kupang Timur, Kabupaten Kupang. Buletin Impas Volume 2, Nomor. 2 Tahun 2020. E-ISSN 2714-8459 HAL. 180-189.

Rahmanta, Iskandarini, Flower T. 2011. Analisis Efisiensi Penggunaan Faktor-Faktor Produksi Pada Usahatani Padi Sawah di Desa Sei Belutu Kecamatan Sei Bamban Kabupaten Serdang Bedagai. Jurnal Ilmiah. Departemen Agribisnis Fakultas Pertanian. (2011).

Rasmussen, S.2011. Production Economics. The Basic Theory of Production Optimisation. Library of Congress Control Number: 2010934762. ISBN 978-3-642-14610-7. Springer.

Rozen, N.; Kasim M., 2018. Teknik Budidaya Tanaman Padi Metode SRI. Rajawali Pers. Depok.

Shinta, A., 2011. Usahatani, Cetakan ke-1 ISBN: 978-602-8960-73-1. Universitas Brawijaya Press: Malang.http://shinta.lecture.ub.ac.id/files/2012/11/Ilmu-Usaha-Tani. Pdf.

Siregar S. 2017. Metode Penelitian Kuantitaf Dilengkapi Dengan Perbandingan Perhitungan Menual 
dan SPSS, Cetakan ke-4, Kencana. Jakarta. (2017). 2017.

Soekartawi. 2004. Agribisnis, Teori dan Aplikasinya Penerbit PT RajaGrafindo Jakarta.

Soekartawi. 2010. Agribisnis. Teori dan Aplikasi. Penerbit PT. Grafindo Persada, Jakarta.

Suek, J., 2018. Risiko, Inefisiensi dan Keberlanjutan Sistem Wanatani Mamar di Wilayah Timor Barat. [Disertasi] Program Pasca Sarjana, Fakultas Pertanian, Universitas Gajah Mada, Yogyakarta.

Sumaryanto, Wahida, \& M.Siregar, 2003. Determinan Efisiensi Teknis Usahatani Padi Di Lahan Sawah Irigasi Jurnal Agro Ekonomi Volume 21 No. 1 Mei 2003 : 72 - 96.

Tinaprilla, N.; N. Kusnadi, B. Sanim, \& D.B. Hakim, 2013. Analisis Efisiensi Teknis Usahatani Padi Di Jawa Barat Indonesia. Jurnal Agribisnis, Vol. 7, No.1.,2013. 14-34. 